\title{
PERSONAL SOCIAL RESPONSIBILITY SEBAGAI AKUNTANSI PERTANGGUNGJAWABAN SOSIAL UNTUK MENINGKATKAN STAKEHOLDER VALUE
}

\author{
Dwi Ekasari Harmadji
}

Universitas Wisnuwardhana Malang

\begin{abstract}
ABSTRAK
Tujuan utama penelitian ini untuk mendeskripsikan pengalaman pribadi mengenai personal social responsibility yang diterapkan oleh $\mathrm{NP}$, seorang wirausaha yang memiliki perusahaan perorangan miliknya yaitu Hotel A di Kota Malang. Hal ini akan menginspirasi bagi wiraswasta lain untuk bisa menghasilkan Personal Social Responsibility di lingkungan usahanya sehingga dapat meningkatkan kesejahteraan masyarakat sekitarnya. Hasil penelitian ini dapat menjadi input yang berguna bagi pengembangan teori stakeholder dan akuntansi pertanggungjawaban sosial melalui penerapan Personal Social Responsibility sehingga dapat meningkatkan stakeholder value dalam wirausaha. Hasil penelitian ini dapat digunakan sebagai bahan referensi untuk penelitian lebih lanjut terutama bagi pihak-pihak yang berkepentingan. Melalui penelitian kualitatif dengan pendekatan naratif deskriptif, penelitian ini menggunakan teori stakeholder, yang lebih mempertimbangkan posisi para stakeholder yang dianggap powerfull daripada hanya posisi shareholder saja. Kelompok-kelompok stakeholder tersebut meliputi pemegang saham, pelanggan, pegawai, pemasok, kreditur, pemerintah, dan masyarakat. Hasil penelitian ini menunjukkan bahwa ada keterkaitan langsung dengan penerapan Personal Social Responsibility sebagai akuntansi pertanggungjawaban sosial untuk meningkatkan stakeholder value.
\end{abstract}

Kata Kunci: Personal Social Responsibility, Akuntansi Pertanggungjawaban Sosial dan Stakeholder Value.

\section{PENDAHULUAN}

Tanggung jawab sosial muncul dan berkembang antara perusahaan dan masyarakat yang sangat ditentukan oleh dampak yang timbul dari perkembangan dan peradaban masyarakat. Semakin tinggi tingkat peradaban masyarakat, khususnya akibat perkembangan ilmu sehingga meningkatkan kesadaran dan perhatian lingkungan memunculkan tuntutan tanggung jawab perusahaan. Hal itu terjadi karena peningkatan pengetahuan masyarakat meningkatkan keterbukaan ekpektasi masa depan dan sustainabilitas pembangunan. Perubahan nilai, norma dan peradaban masyarakat menuntut tanggung jawab perusahaan secara meluas. Di situlah letak peran social responsibility yang merupakan bagian dari perluasan tanggung jawab perusahaan. Batasan konsep social responsibility, mengalami perkembangan dalam sejarah 
keberadaannya. Perkembangan social responsibility di breakdown menjadi tiga periode, yaitu:

1. Perkembangan awal yang masih diwarnai konsep tradisional yaitu antara 1950-1960.

2. Perkembangan pertengahan antara tahun 1970-1980.

3. Perkembangan era tahun 1990 -an sampai sekarang.

Personal social responsibility (PSR) merupakan wujud tanggung jawab sosial bagi wirausaha perorangan terhadap lingkungan alam dan sosial masyarakat, yang diwujudkan dalam akuntansi pertanggungjawaban sosial untuk meningkatkan stakeholder value dan berimplikasi pada sustainability usahanya. Menurut Wahyudi dan Azheri (2008:14) tanggung jawab sosial secara umum sebenarnya tidak jauh berbeda dengan konsep tanggung jawab itu sendiri. Seperti tanggung jawab sosial dengan aktivitas perusahaan, dapat dikatakan bahwa tanggung jawab sosial lebih menekankan pada kepedulian perusahaan terhadap kepentingan stakeholders. Dengan begitu konsep tanggung jawab sosial lebih menekankan pada tanggung jawab perusahaan atas tindakan dan kegiatan usahanya yang berdampak pada orang-orang tertentu, masyarakat, dan lingkungan di mana perusahaan tersebut melakukan aktivitas usahanya. Tuntutan disclosure yang lebih baik dari para stakeholder (pemegang saham, pelanggan, pegawai, pemegang saham serta masyarakat) membutuhkan pelaporan yang akurat berasal dari sumber data yang terpercaya. Hal ini dapat meningkatkan stakeholder value.

Pendekatan nilai stakeholder (stakeholder value approach) adalah filosofi manajemen yang menganggap maksimalisasi kepentingan kepada semua stakeholder (pelanggan, pegawai, pemegang saham, dan masyarakat) sebagai tujuan tertinggi. Tujuannya adalah untuk memaksimalkan nilai ini dengan mengikuti kebijakan-kebijakan antara lain sebagai berikut:

(1) Meminimalkan biaya dan dampak negatif, sekaligus meningkatkan kualitas produknya

(2) Meningkatkan keterampilan dan kepuasan pegawai

(3) Memberikan kontribusi pada pengembangan masyarakat

Rumusan masalah ini adalah bagaimana personal social responsibility sebagai akuntansi pertanggungjawaban sosial dapat meningkatkan stakeholder value? Tujuannya untuk meningkatkan pemahaman secara mendalam atas esensi makna dari personal social responsibility sebagai akuntansi pertanggungjawaban sosial untuk meningkatkan stakeholder value.

\section{TINJAUAN PUSTAKA}

Pentingnya kesadaran penerapan personal social responsibility sebagai akuntansi pertanggungjawaban sosial dapat diterapkan di perusahaan perorangan, UMKM (Usaha 
Mikro Kecil dan Menengah) serta wirausaha, karena dengan penerapan PSR dapat meningkatkan stakeholder value, antara lain masyarakat di sekitar lingkungan usaha bisa ikut sejahtera, karena mereka dilibatkan dalam usaha tersebut. Penelitian ini menjelaskan keterlibatan PSR sebagai akuntansi pertanggungjawaban sosial untuk meningkatkan stakeholder value sebagai berikut:

\section{Personal Social Responsibility (PSR)}

PSR memiliki peranan penting dalam lingkungan sosial masyarakat yang mempengaruhi kesejahteraan masyarakat sekitar dan kelestarian alam, hal ini juga dikemukakan dalam laman elektronik di The American Program Bureau (http://www.apbspeakers.com/personal-social-responsibility-speakers.html): "Personal social responsibility (PSR) may appear to be a new concept in relation to corporate social responsibility, but it is a concept as old as The Golden Rule -- do unto others as you would have done to you. PSR expands on this by promoting a proactive stance towards positively influencing and affecting the people and environments around you."

Kutipan tersebut diatas diterjemahkan sebagai berikut: Tanggung jawab sosial pribadi mungkin tampak sebuah konsep baru dalam kaitannya dengan tanggung jawab sosial perusahaan, tetapi merupakan konsep setua the golden rule. Perlakukan kepada orang lain seperti anda akan melakukan untuk diri anda sendiri. PSR memperluas ini dengan mempromosikan sikap proaktif positif yang mempengaruhi dan dipengaruhi orang-orang serta lingkungan di sekitar Anda.

Pernyataan PSR juga disebutkan dalam laman elektronik sebagai berikut: http://www.arvinddevalia.com/blog/2007/01/31/personal-social-responsibility-is-hereto-stay/:

Kutipan dimaksud diterjemahkan sebagai berikut: PSR adalah segala sesuatu yang dilakukan untuk orang lain dan apa yang anda ingin orang lain lakukan untuk anda. Hal ini untuk mengenali perilaku anda yang dapat mempengaruhi orang lain, dan bertanggung jawab atas tindakan anda. Misalnya, seseorang yang sopan kontras dengan seseorang bersikap kasar. Idealnya PSR menyadari:

1. Usahanya untuk selalu memiliki efek positif pada orang lain

2. Pola pikir yang dimiliki untuk berkontribusi bagi orang lain

3. Sikap menahan diri dari menyebabkan pengaruh negatif di lingkungannya

4. Melakukan kegiatan sosial dan ekonomi yang akan memiliki dampak positif terhadap lingkungan.

Tujuan utama dari teori stakeholder adalah untuk membantu manajemen perusahaan dalam meningkatkan penciptaan nilai sebagai dampak dari aktivitas-aktivitas yang mereka lakukan dan meminimalkan kerugian yang mungkin muncul bagi stakeholder mereka. Dengan kata lain, teori ini menjelaskan hubungan antara manajemen perusahaan dengan para stakeholder-nya. Para stakeholder memiliki hak untuk diperlakukan secara adil oleh organisasi, dan manajemen harus mengelola organisasi untuk keuntungan seluruh stakeholder (Ulum, 2008). Menurut teori stakeholder, manajemen sebuah 
organisasi diharapkan melakukan aktivitas yang dianggap penting oleh para stakeholder mereka dan kemudian melaporkan kembali aktivitas-aktivitas tersebut kepada para stakeholder. Kelompok stakeholder inilah yang menjadi bahan pertimbangan utama bagi manajemen perusahaan dalam mengungkapkan atau tidak mengungkapkan suatu informasi di dalam laporan.

\section{Akuntansi Pertanggungjawaban Sosial}

Dalam rangka melaksanakan aktivitas sosialnya, perusahaan atau perorangan (sebagai wirausaha) mengeluarkan biaya-biaya sosial yang dapat disusun menjadi laporan akuntansi pertanggungjawaban. Definisi akuntansi pertanggungjawaban sosial atau SEA menurut Belkaoui dalam bukunya tentang socio economic accounting yang dikutip Harahap (2003:349) yaitu: "SEA timbul dari penerapan akuntansi dalam ilmu sosial, ini menyangkut pengaturan, pengukuran analisis, dan pengungkapaan pengaruh ekonomi dan sosial dari kegiatan pemerintah dan perusahaan. Hal ini termasuk kegiatan yang bersifat mikro dan makro. Pada tingkat makro bertujuan untuk mengukur dan mengungkapkan kegiataan ekonomi dan sosial negara mencakup social accounting and reporting peranan akuntansi dalam pembangunan ekonomi. Pada tingkat mikro bertujuan untuk mengukur dan melaporkan pengaruh kegiatan perusahaaan terhadap lingkungannya, mencakup: financial dan managerial social accounting, social auditing”.

Ada tiga tujuan akuntansi pertanggungjawaban sosial menurut Ramanathan yang dikutip oleh Usmansyah (1989:21-22) yaitu:

1) Untuk mengidentifikasikan dan mengukur sumbangan sosial netto periodik dari suatu perusahaan, yang meliputi bukan hanya biaya dan manfaat yang diinternalisasikan ke dalam perusahaan, namun juga yang timbul dari eksternalitas yang mempengaruhi bagian-bagian sosial yang berbeda.

2) Untuk membantu menentukan apakah praktek dan strategi perusahaan yang secara langsung mempengaruhi sumber daya relatif dan keadaan sosial adalah konsisten dengan prioritas-prioritas sosial pada satu sisi dan aspirasi-aspirasi individu pada sisi lainnya.

3) Untuk menyediakan dengan cara yang optimal bagi semua kelompok sosial, informasi yang relevan mengenai tujuan, kebijakan, program, kinerja dan sumbangan perusahaan pada tujuan-tujuan sosial.

\section{Peningkatan Stakeholder Value}

Stakeholderl pemangku kepentingan adalah pelanggan, pegawai, masyarakat dan lingkungan alam serta perekonomian.

Kegagalan dalam mengelola akuntansi pertanggungjawaban sosial, selain merugikan wirausaha, juga berdampak langsung pada stakeholder dalam bentuk antara lain:

a. Dampak pada pemilik wirausaha:

Hilangnya seluruh investasi mereka karena bangkrutnya usaha. 
$>$ Penurunan jumlah pelanggan karena reputasi yang buruk.

> Hilangnya dividen sebagai akibat dari penurunan laba perusahaan.

$>$ Pemilik wirausaha bertanggung jawab atas kerugian yang terjadi pada perusahaannya.

b. Dampak pada pegawai

$>$ Tindakan indisipliner karena kesengajaan atau kealpaan.

$>$ Kehilangan pendapatan, misalnya penurunan bonus atau penundaan peningkatan upah, karena dampak pada pendapatan/laba perusahaan.

Kehilangan pekerjaan apabila usaha bangkrut.

c. Dampak pada pelanggan

Dampak terhadap pelanggan memang tidak langsung dan tidak terlihat jelas namun tetap dirasakan, seperti:

$>$ Penurunan kualitas layanan pelanggan

$>$ Penurunan ketersediaan produk

$>$ Krisis likuiditas

$>$ Perubahan peraturan

d. Dampak pada lingkungan sosial dan perekonomian

Jika perusahaan bangkrut maka, banyak pegawai kehilangan pekerjaan karena PHK, sehingga akan menurunkan pendapatan per kapita dan kesejahteraan turun drastis.

e. Dampak pada masyarakat

Jika perusahaan bangkrut, maka banyak pegawai yang menganggur sehingga membuat tingkat kejahatan/kriminalitas meningkat.Penjelasan tersebut diatas, dapat dijelaskan dalam Tentative Theory sebagai berikut:

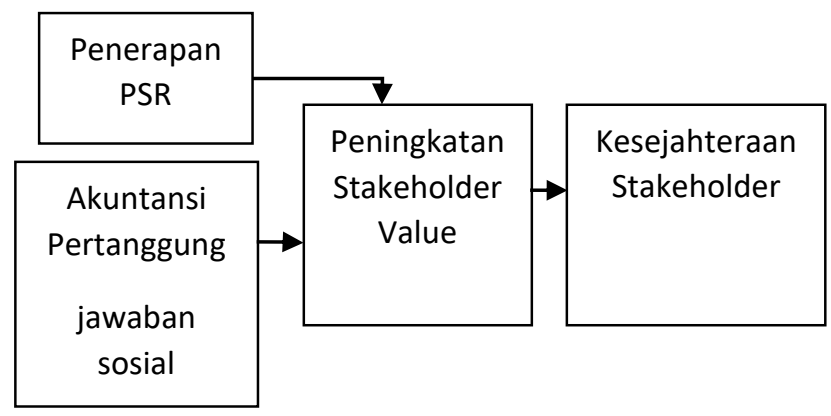

Bagan tentative theory diatas menggambarkan penerapan PSR sebagai akuntansi pertanggungjawaban sosial yang dapat memberikan dampak peningkatan stakeholder value dan berujung pada kesejahteraan stakeholder. Tentative theory diperlukan untuk menggambarkan alur penelitian ini.

\section{METODE PENELITIAN}


Metode penelitian yang digunakan dalam penelitian ini adalah penelitian kualitatif dengan pendekatan naratif yang mendeskripsikan secara kronologis usaha yang dirintis oleh NP ketika mendirikan Hotel A dengan tujuannya untuk kesejahteraan masyarakat di sekitar Hotel A. Beliau merekrut masyarakat di lingkungan Hotel A tanpa melihat ijazah/level pendidikan dan SARA (suku agama dan ras). Pegawai yang direkrut tidak memiliki dasar pengetahuan perhotelan karena ada yang mantan preman, ada pemuda putus sekolah, ada pegawai yang merupakan anak yatim piatu, ada pula pegawai yang pendidikannya tidak lulus SD, dan sebagainya. Ibu NP hanyalah seorang ibu rumah tangga yang bukan sarjana, tetapi sudah melakukan penerapan PSR untuk meningkatkan stakeholder value dan kesejahteraan stakeholder.

\section{Situs dan Pengumpulan Data Penelitian}

Ibu NP merupakan key informant sekaligus tokoh dan unit analisis dalam penelitian ini. Dengan pertimbangan bahwa Ibu NP merupakan aktor yang terjun langsung dalam proses $P S R$ sebagai akuntansi pertanggungjawaban sosial untuk peningkatan stakeholder value. Pengumpulan fakta-fakta sosial dilakukan melalui wawancara dan pengamatan berperan serta (participant observation). Ludigdo (2007) mengungkapkan bahwa dengan metode participant observation, peneliti harus berusaha terlibat di dalam suatu proses kehidupan sosial sehari-hari di mana interaksi sosial berlangsung, dalam penelitian ini keterlibatan peneliti dalam aktifitas sehari-hari Ibu NP berlangsung selama seminggu. Dalam metode ini peneliti secara otomatis terlibat dalam dialog-dialog interaktif dengan Ibu NP dan para pegawai Hotel A. Dialog ini merupakan suatu bentuk wawancara yang berlangsung secara alamiah, bersifat informal dan tidak terstruktur. Selain itu peneliti juga dapat turut merasakan suasana budaya kekeluargaan dalam organisasi Hotel A yang tidak tampak secara eksplisit.

\section{Teknis Analisis}

Analisis data sebagai upaya mencari dan menata secara sistematis catatan hasil observasi, wawancara, dan lainnya untuk meningkatkan pemahaman peneliti tentang kasus yang diteliti dan menyajikannya sebagai temuan bagi orang lain. Menurut Muhadjir, 2000:14 dilakukan dalam tiga langkah analisis data sebagaimana berikut ini:

1. Peneliti melakukan reduksi data. Proses ini dilakukan dengan melakukan penyederhanaan, pengabstrakan dan transformasi data "kasar" yang muncul dari catatan tertulis di lapangan (fieldnotes) yang dilakukan. Proses ini berlangsung baik pada saat peneliti masih di lapangan maupun pada saat sudah meninggalkan lapangan.

2. Penyajian data (data display), yaitu merupakan sekumpulan informasi tersusun yang memberi kemungkinan adanya penarikan kesimpulan dan pengambilan tindakan. Spardley (1997) menjelaskan dalam kerangkanya bahwa proses ini boleh disetarakan dengan analisis domain dimana peneliti mengategorikan berbagai ungkapan dan realitas sosial yang ditemui secara tematik. Pada fase ini peneliti dapat memanfaatkan bantuan teori, khususnya untuk menyusun kerangka domain (atau tema). 
3. Penarikan kesimpulan, verifikasi, dan refleksi. Pada proses ini peneliti melakukan interpretasi terhadap makna dari berbagai bahan empirik yang telah dikumpulkan dan dikategorisasikan secara tematik sebagaimana telah dilakukan dalam proses sebelumnya. Sedangkan proses verifikasi dilakukan secara dinamis dalam berbagai situasi praktis di lapangan dan di luar lapangan, bagaimanapun ini dilakukan untuk memastikan kesesuaian data dan sekaligus menjaga kredibilitas informan. Sementara itu proses refleksi dilakukan untuk mendapatkan pemahaman yang benar dan utuh atas kehidupan pribadi Ibu NP dalam realitas sosialnya. Untuk ini dilakukan sintesa antara temuan empiris dengan ungkapan konsepsional-teoritis.

\section{Instrumen Analisis}

Penelitian ini adalah berkisar tentang program Personal Social Responsibility sebagai akuntansi pertanggungjawaban sosial untuk peningkatan Stakeholder Value. Chariri dan Ghazali (2007:32) menyatakan bahwa teori stakeholder berpendapat bahwa perusahaan bukanlah entitas yang hanya beroperasi untuk kepentingannya sendiri namun memberikan manfaat bagi stakeholders, Di dalam perusahaan adanya pihak yang diutamakan yaitu pemangku kepentingan/stakeholders. (shareholders, kreditur, pelanggan/konsumen, supplier/vendor, pemerintah, masyarakat, lingkungan sosial dan perekonomian). Di Hotel Armi yang menjadi stakeholders dalam hal ini adalah pegawai, pelanggan, dan masyarakat.

\section{Jenis dan Sumber Data}

Data yang diperlukan dalam penelitian ini adalah berupa data primer dan data sekunder. Data primer dalam penelitian ini meliputi pengamatan langsung dan wawancara dengan Ibu NP sebagai key informant. Sedangkan data sekunder diperoleh dari co-informant yang meliputi beberapa orang pegawai Hotel A, Romo EI (Seorang Pastur, Rohaniwan) dan Ibu S (sahabat dekat Ibu NP). Sedangkan data sekunder tambahan lainnya adalah data yang dikumpulkan dan diolah, seperti foto, struktur organisasi dan laporan keuangan lainnya.

\section{Teknis Analisis Data}

Pengumpulan data yang dilakukan dengan cara wawancara dengan key informant untuk memperoleh data primer dan data sekunder diperoleh dari co-informant. Key informant adalah Ibu NP, sedangkan co-informant adalah beberapa orang pegawai Hotel Armi, Romo EI (Seorang Pastur, Rohaniwan) dan Ibu S (sahabat dekat Ibu NP) untuk mengetahui keterkaitan konteks permasalahan dengan subyek penelitian dan untuk memperoleh klarifikasi. Hal ini dilakukan dengan proses wawancara.

Selanjutnya klarifikasi data dengan triangulasi, yaitu kegiatan untuk menyusun kebenaran data yang diperoleh dari berbagai sudut pandang yang berbeda.

\section{Uji Keabsahan Penelitian}


Menurut Leksono (2013) menetapkan keabsahan data (data trustworthiness) diperlukan teknis pemeriksaan yang didasarkan atas sejumlah kriteria tertentu. Tersedia 4 kriteria untuk uji keabsahan data yaitu:

a. Credibility (derajat kepercayaan)

b. Transferability (keterbukaan)

c. Dependability (kebergantungan)

d. Confirmability (kepastian usaha)

Keempat pengujian diatas yang paling utama adalah uji kredibilitas (credibility) data, yaitu dengan melakukan perpanjangan pengamatan, meningkatkan ketekunan, triangulasi, diskusi teman sejawat, member check, dan analisis kasus negatif. Pengujian kredibilitas data menggunakan teknik triangulasi.

Teknik triangulasi berarti peneliti menggunakan teknik pengumpulan data yang berbeda-beda untuk mendapatkan data dari sumber yang sama yaitu teknik observasi partisipatif, wawancara mendalam, dan studi dokumentasi untuk sumber data yang sama secara serentak. Triangulasi juga dapat diartikan sebagai teknik pengumpulan data yang bersifat menggabungkan berbagai teknik pengumpulan data dari sumber data yang ada. Pengujian keabsahan data dalam penelitian ini dilakukan dengan:

- Triangulasi pengumpulan data, dilakukan dengan membandingkan data yang dikumpulkan melalui wawancara dengan data yang diperoleh melalui observasi atau informasi yang diperoleh melalui studi dokumentasi.

- Triangulasi sumber data, dilakukan dengan cara menanyakan kebenaran suatu data atau informasi yang diperoleh dari seorang informan kepada informan lainnya.

- Pengecekan anggota dilakukan dengan cara menunjukkan data atau informasi, termasuk interpretasi peneliti yang telah disusun dalam format catatan lapangan. Catatan lapangan dikonfirmasi langsung dengan informan untuk mendapatkan komentar dan melengkapi informasi lain yang dianggap perlu.

- Diskusi dengan teman sejawat dilakukan terhadap orang yang menurut peneliti memiliki pengetahuan dan keahlian yang relevan, agar data dan informasi yang telah dikumpulkan dapat didiskusikan dan dibahas untuk menyempurnakan data penelitian.

\section{HASIL DAN PEMBAHASAN}

Dalam merajut program PSR sebagai akuntansi pertanggungjawaban sosial untuk peningkatan stakeholder value yang dilakukan oleh Ibu NP, khususnya di Hotel A dalam praktiknya, pada bagian berikut juga akan dijelaskan secara mendalam untuk merefleksikan pemahaman atas PSR. Bagian ini merupakan hasil refleksi atas pemahaman mengenai sikap pegawai di Hotel A terkait dengan penerapan PSR dalam realitas praktiknya, yang merupakan hasil temuan peneliti di lapangan. 


\section{Pemahaman 1: Pegawai Hotel A Menganggap Ibu NP sebagai Malaikat Penolong}

Di Hotel A, beberapa pegawai menganggap Ibu NP sebagai malaikat penolong karena beliau mengangkat harkat hidup mereka yang sebelumnya hanya pengangguran luntang lantung tanpa mata pencaharian tetap, sekarang diberikan pekerjaan. Berikut penuturan pegawai Hotel A atas nama Bapak H yang menggambarkan hal tersebut:

"Ibu NP adalah malaikat penolong yang dikirim Tuhan untuk saya dan keluarga karena bisa mendapatkan gaji dan pekerjaan di Hotel A. Dulunya saya hanya pemuda pengangguran yang tidak punya kerjaan tetap“.

\section{Pemahaman 2 : Pegawai Hotel A menganggap Ibu NP sebagai sosok pribadi yang disiplin, tegas dan berwibawa.}

Suatu ketika dilakukan wawancara tidak terstruktur kepada pegawai Hotel A Bapak IS sebagai berikut:

"Ibu NP seorang wanita yang disiplin, tegas dan berwibawa sehingga sanggup merubah saya yang dulunya preman kampung menjadi pegawai di hotel ini. Dulu saya dibenci orang, sekarang saya disayang orang terutama pelanggan hotel”.

\section{Pemahaman 3 : Pegawai Hotel A menganggap Ibu Nelly sebagai seorang wanita dermawan yang penuh welas asih.}

Ibu NP menerapkan prinsip PSR, sebagai akuntansi pertanggungjawaban sosial yang relevan dan up to date, sehingga berakibat pada peningkatan stakeholder value. Berikut penuturan pegawai Hotel Armi bernama Ibu A:

"Ibu NP memang berjiwa sosial dengan menyumbang dan menggalang donatur untuk perbaikan sekolah rusak, santunan ke panti asuhan juga Ibu NP seorang dermawan dan penuh welas asih terhadap orang-orang yang miskin di sekitar Hotel A"

Berikut disampaikan tabel mengenai hasil wawancara dengan key informant dan co informan:

1) Ibu NP sebagai Key Informant

"Aku menggalang gerakan orang tua asuh untuk orang-orang berkekurangan, dan memperbaiki sekolah-sekolah yang rusak. Para donatur semakin bersemangat karena mereka kuundang untuk melihat buah kebaikan mereka dan memeriksa apakah dana-dana sudah dipakai sesuai dengan ujuan aslinya. Akhirnya kutemukan kebenaran ini: lebih baik memberi daripada menerima".

Pemaknaan: PSR dianggap sebagai akuntansi pertanggungjawaban sosial.

2) Bp. H Pegawai Hotel Armi/Co Informant

"Ibu NP seperti malaikat penolong yang dikirim Tuhan untuk saya dan keluarga karena bisa mendapatkan gaji dan pekerjaan di Hotel A. Dulunya saya hanya pemuda pengangguran yang tidak punya kerjaan tetap".

Pemaknaan: PSR dianggap sebagai akuntansi pertanggungjawaban sosial untuk peningkatan stakeholder value. 


\section{3) Bapak IS /Pegawai Hotel Armi / Co Informant}

"Ibu NP adalah seorang wanita yang disiplin, tegas dan berwibawa sehingga sanggup merubah saya yang dulunya preman kampung menjadi pegawai Hotel A. Dulu saya dibenci orang, sekarang saya disayang orang terutama pelanggan hotel”.

Pemaknaan: PSR dianggap sebagai akuntansi pertanggungjawaban sosial untuk peningkatan stakeholder value.

4) Ibu A Pegawai Hotel Armi/ Co Informant

"Ibu Nelly memang berjiwa sosial dengan menyumbang dan menggalang donatur untuk perbaikan sekolah rusak, santunan ke panti asuhan juga Ibu NP memang dermawan dan penuh welas asih terhadap orang-orang yang miskin di sekitar Hotel A"

Pemaknaan: PSR dianggap sebagai akuntansi pertanggungjawaban sosial untuk peningkatan stakeholder value.

5) Ibu S donatur PSR/ Co Informant

"Ibu NP orangnya baik dan pintar menggalang dana untuk kegiatan sosial yang nyata seperti perbaikan sekolah rusak, panti asuhan, dsb"

Pemaknaan: PSR dianggap sebagai akuntansi pertanggungjawaban sosial.

6) Romo EI / Co Informant

"Ibu NP orang yang welas asih dan suka memberi daripada menerima. Beliau juga bisa diajak kerjasama di kegiatan sosial, penggalang dana yang baik karena memiliki relasi yang banyak"

Pemaknaan: PSR dianggap sebagai akuntansi pertanggungjawaban sosial.

Dari pernyataan-pernyataan diatas, tercermin bahwa kegiatan dan pernyataan datadata tersebut diatas merupakan ungkapan langsung pegawai Hotel A mengenai sosok Ibu NP yang menjalankan program $P S R$ sebagai akuntansi pertanggungjawaban sosial untuk peningkatan stakeholder value. Rasa welas asih membuat Ibu NP menjalankan program PSR sebagai akuntansi pertanggungjawaban sosial untuk peningkatan stakeholder value dengan sukarela dan tanpa keterpaksaan.

\section{PEMBAHASAN}

Menggunakan teori stakeholder yang berpendapat bahwa perusahaan bukanlah entitas yang hanya beroperasi untuk kepentingannya sendiri, namun memberikan manfaat pada stakeholder (Chariri dan Ghozali,2007). Di dalam perusahaan Hotel A terdapat pihak yang diutamakan yaitu: pelanggan, pegawai, masyarakat. Dengan adanya kepentingan stakeholder, maka diperlukan program PSR yang relevan dan real.

\section{- Makna Personal Social Responsibility (PSR)}

PSR bagi Ibu NP adalah segala sesuatu yang dilakukan untuk menolong orang lain yang miskin secara materi. Ibu NP sangat ideal dalam penerapan PSR yang menyadari akan:

1) Selalu berusaha untuk memiliki efek positif pada orang lain.

2) Memiliki pola pikir untuk berkontribusi bagi orang lain. 
3) Menahan diri dari menyebabkan pengaruh negatif di lingkungannya misalnya dengan melemparkan sampah di tanah, atau dengan bergosip.

4) Melakukan kegiatan sosial dan ekonomi Nya yang akan memiliki dampak positif atau netral terhadap lingkungan.

\section{- Makna PSR sebagai Akuntansi Pertanggungjawaban Sosial}

Ibu NP yang berjiwa sosial melaksanakan PSR dengan menggalang dana dari donatur dan mempertanggungjawabkan penggunaan dana tersebut untuk kegiatan-kegiatan sosial untuk menolong orang miskin secara materi.

Ibu NP bertanggungjawab secara sosial dan berusaha untuk memiliki dampak positif pada orang lain dan memperkaya lingkungannya. Dia akan berusaha untuk memberikan kontribusi positif, dan tidak akan mencemari atmosfer lingkungannya, baik secara fisik maupun kiasan.

\section{- Makna PSR untuk Peningkatan Stakeholder Value}

Stakeholder Hotel A adalah pelanggan, pegawai dan masyarakat. Makna PSR yang dilakukan oleh Ibu NP dirasakan langsung oleh pelanggan, pegawai Hotel A dan kesejahteraan masyarakat meningkat.

\section{- Makna PSR untuk Ibu NP}

Makna PSR untuk Ibu NP adalah semboyan yang dia miliki yaitu: lebih baik memberi daripada menerima dan menjadi sosok yang penuh welas asih bagi sesama manusia. Ibu NP senang memberikan sumbangan uang, tenaga dan pikiran untuk kesejahteraan masyarakat.

Peran Ibu NP dalam penggalangan dana dari para donatur dalam peningkatan stakeholder value dirasakan oleh masyarakat yang membutuhkan. Keinginan untuk memberikan kesejahteraan bagi para pegawai Hotel A membuat Ibu NP berani mengambil keputusan untuk ekspansi Hotel A dengan dana pinjaman kredit dari Bank BNI 46 (kreditur). Bila dilihat dari teori stakeholder, Ibu Nelly juga memiliki PSR yang dapat meningkatkan stakeholder value kreditur dengan kepercayaan untuk memberikan pinjaman kredit dalam upaya ekspansi Hotel A.

Hubungan dengan pelanggan sebagai stakeholder juga dijalankan dengan mengembangkan relasi yang baik, sehingga pelanggan merasa puas dan loyal kepada Hotel Armi. Implikasinya adalah tingkat hunian Hotel A selalu penuh. Melalui PSR ada dampak positif yang dirasakan Ibu NP karena usaha Hotel A eksis dan tetap survive meskipun banyak hotel baru bermunculan di Kota Malang. Hotel A juga growth/ berkembang, yang pada awal berdirinya hanya terdiri dari 10 kamar, sekarang berkembang menjadi 50 kamar.

Kendala yang terjadi dalam peningkatan stakeholder value adalah pola pikir pegawai yang berani melakukan kecurangan/fraud dan ketidakjujuran dalam bekerja yang 
menjadikan contoh/preseden yang tidak baik bagi pegawai lainnya. Jalan keluarnya adalah dengan mengajaknya bicara secara kekeluargaan dan merubah pola pikir/mindset pegawai bahwa peningkatan PSR untuk sustainability/ keberlangsungan usaha Hotel A adalah pekerjaan yang menyenangkan dan memberikan dampak langsung untuk kesejahteraan para pegawai secara adil dan merata. Hal ini diwujudkan dengan adanya pemberian bonus uang bagi seluruh pegawai hotel, jika kamar terisi dengan okupansi (tingkat hunian hotel) 95\% kamar penuh. Hadiah/reward bonus ini diberikan secara bulanan, dan untuk keseluruhan pegawai Hotel A. Hadiahnya dalam bentuk tambahan bonus uang yang disediakan oleh Ibu NP.

Berdasarkan penggalian mendalam mengenai esensi makna PSR dapat digambarkan pada bagan real theory construct.

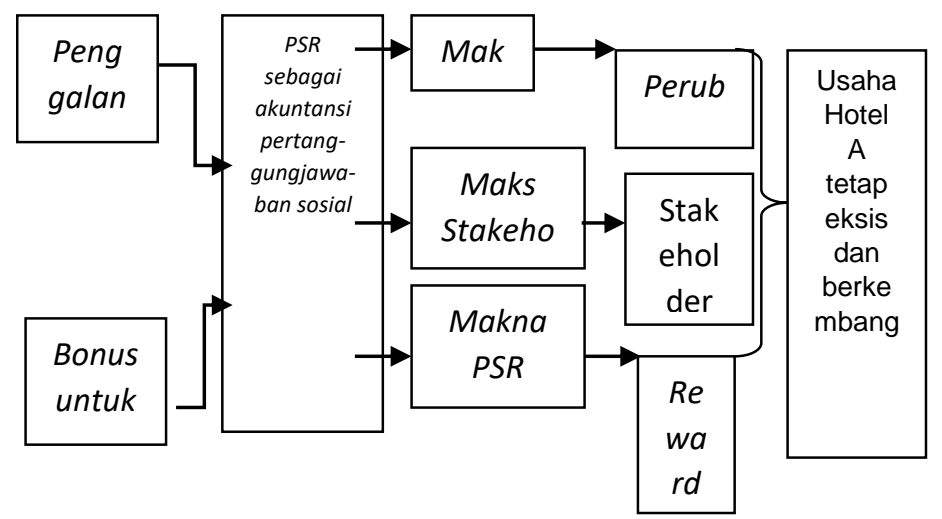

Bagan Real Theory Construct merupakan hasil pengamatan di lapangan dan penelitian yang merupakan pengembangan teori berdasarkan realitas di lapangan, dan merupakan hasil akhir dari tentative theory. Penjelasan bagan tersebut diatas adalah: penggalangan dana dari donatur dan bonus untuk kesejahteraan pegawai merupakan aktivitas riil dari PSR sebagai akuntansi pertanggungjawaban sosial, sehingga memberikan makna PSR termasuk makna PSR untuk Ibu Nelly dan maksimalisasi stakeholder value sehingga berimplikasi pada perubahan mindset, kesejahteraan stakeholder dan peningkatan reward/bonus. Implikasinya adalah usaha Hotel Armi tetap eksis dan berkembang. Hal ini menunjukkan bahwa program PSR sebagai akuntasi pertanggungjawaban sosial untuk meningkatkan stakeholder value sudah dijalankan secara efektif.

\section{KESIMPULAN DAN SARAN}

- Kesimpulan

a) Program PSR sebagai akuntansi pertanggungjawaban sosial diperlukan dalam rangka meningkatkan stakeholder value, karena jika PSR sudah dilaksanakan secara efektif, akan meningkatkan kesejahteraan stakeholder value yang pada akhirnya juga akan 
menyebabkan usaha perorangan/wiraswasta tersebut tetap eksis dan berkembang menjadi besar.

b) Pihak-pihak yang terlibat dalam PSR yang dijalankan oleh Ibu NP adalah Ibu NP itu sendiri sebagai donatur dan saudara, sahabat, kenalan/relasi dan para donatur lain yang bersedia menyumbangkan dananya untuk membantu kegiatan sosial yang disponsori oleh Ibu NP. Penggunaan dana yang sudah terkumpul untuk kegiatan sosial dan dipertanggungjawabkan oleh Ibu NP dalam bentuk laporan keuangan dan bukti dokumentasi berupa foto-foto kegiatan sosial yang disampaikan kepada semua donatur yang berpartisipasi dalam kegiatan sosial (hal ini merupakan wujud akuntansi pertanggungjawaban sosial yang dilakukan oleh Ibu NP).

c) Kendala yang dihadapi dalam usaha peningkatan PSR adalah pola pikir pegawai yang melakukan kecurangan/ fraud dalam bekerja, sehingga menjadi "beban" dan preseden yang tidak baik bagi pegawai lainnya.

d) Solusi yang diperlukan untuk mengatasi kecurangan / fraud adalah dengan mengajaknya bicara secara kekeluargaan dan diberikan pengertian agar merubah pola pikir pegawai di Hotel A dan dengan memberikan motivasi berupa hadiah bonus uang bila Hotel Armi mencapai tingkat okupansi 95\%.

- Saran

a. Sosialisasi lebih intens ke seluruh pegawai Hotel A agar memiliki pola pikir/mindset kejujuran dan kebersihan dalam bekerja.

b. Pemberian hadiah/reward lebih intensif diberikan kepada pegawai yang disiplin, jujur dan bekerja dengan rajin

c. Program peningkatan PSR harus dilakukan secara berkesinambungan, karena dapat memaksimalkan stakeholder value dan bermanfaat bagi keberlangsungan dan pengembangan usaha yang dimiliki oleh organisasi atau perusahaan perorangan.

\section{DAFTAR PUSTAKA}

Chariri Anis dan Imam Ghozali, 2007. Teori Akuntansi Badan Penerbit UNDIP Semarang. 
Harahap, Sofyan. 2003. Teori Akuntansi, Edisi Revisi. Jakarta: PT. Raja Grafindo Persada.

Leksono, Sonny (2013). Penelitian Kualitatif Ilmu Ekonomi dari Metodologi ke Metode. Penerbit PT. Raja Grafindo Persada, Jakarta.

Ludigdo, Unti. 2007. Paradoks Etika Akuntan. Yogyakarta: Pustaka Pelajar.

Muhadjir, Noeng. 2000. Metodologi Penelitian Kualitatif Edisi IV. Yogyakarta: Rake Sarasin.

Paskalis Edwin, 2015. Cinta Tak Berujung. Malang: Penerbit Dioma.

Spradley, James P. 1997. Metode Etnografi. Yogyakarta: Tiara Wacana

Ulum.2008."Intellectual Capital Performance Sektor Perbankan di Indonesia”. Jurnal Akuntansi dan Keuangan.10.(2).77-84

Usmansyah. 1989. Telaah Alternatif Penerapan Akuntansi Pertanggungjawaban Sosial di Indonesia. Akuntansi, No. 10 (Oktober).

Wahyudi, Isa dan Busyra Azheri. 2008. Corporate Social Responsibility, Prinsip, Pengaturan dan Implementasi. Perpustakaan Nasional RI, Katalog dalam terbitan (RDT).

http://www.apbspeakers.com/personal-social-responsibility-speakers.html http://www.arvinddevalia.com/blog/2007/01/31/personal-social-responsibility-is-hereto-stay/

Website: http://prinsipetikabisnis_pustakamanajemen.html 